\title{
ANALISIS PENGARUH TINGGI JATUHNYA AIR (HEAD) TERHADAP DAYA PEMBANGKIT LISTRIK TENAGA MICRO HYDRO TIPE TURBIN PELTON
}

\author{
SURIANTO BUYUNG
}

\author{
Jurusan Teknik Mesin \\ Program Study Diploma IV \\ Politeknik Katolik Saint Paul Sorong \\ Email :buyung.surianto@gmail.com
}

\begin{abstract}
ABSTRAK
Analisis ini dilakukan untuk mengetahui Pengaruh Tinggi Jatuhnya Air (Head) Terhadap Daya Pembangkit Listrik Tenaga Micro Hydro Tipe Turbin Pelton. Untuk mengetahui Pengaruh Tinggi Jatuhnya Air (Head) Terhadap Daya Pembangkit Listrik Tenaga Micro Hydro Tipe Turbin Pelton maka terlihat bahwa head actual dan debit air sangat mempengaruhi daya listrik yang dihasilkan oleh micro hydro. Semakin tinggi jatuh air (Head Actual) dan semakin banyak debit air yang keluar dari Nozzle maka semakin besar juga tegangan listrik yang dihasilkan oleh Micro Hydro. Pada head actual 6,6 meter dengan head efektik 4,4 meter menghasilkan debit air 0,000796 $\mathrm{m}^{3} / \mathrm{s}$, daya turbin 27,499 Watt dan daya micro hydro 24,749 Watt. Sedangkan pada head actual 6 meter dengan head effektif 4 meter menghasilkan debit air 0,000777 $\mathrm{m}^{3} / \mathrm{s}$, daya turbin 24,3849 Watt dan daya micro hydro 21,946 Watt.
\end{abstract}

Kata Kunci : Head Actual, Micro Hydro, Turbin Pelton

\begin{abstract}
This analysis was conducted to determine the effect of the Fall High Water (Head) Against Power Micro Hydro Power Plant Turbine type Pelton. To know the effect of the Fall High Water (Head) Against Power Micro Hydro Power Plant Turbine type Pelton it is seen that the actual head and water flow greatly affects the electrical power generated by micro hydro. The higher the falling water (Head Actual) and the more water flow out of the nozzle, the greater the electrical voltage produced by Micro Hydro. In the actual head of 6.6 meters with 4.4 meters head effective 0.000796 generate water flow $\mathrm{m}^{3} / \mathrm{s}$, the turbine power wattage and power 27.49924 .749 watt micro hydro. While the actual head of 6 meters by 4 meters head effectively produce water discharge $0.000777 \mathrm{~m}^{3} / \mathrm{s}$, the turbine power wattage and power 24.384521 .946 watt micro hydro.
\end{abstract}

Keywords: Head Actual, Micro Hydro, Pelton Turbines

\section{PENDAHULUAN}

Energi adalah kebutuhan pokok manusia untuk melakukan aktivitas sehari-hari. Perkembangan teknologi dan industri yang pesat akan mendorong peningkatan kebutuhan energi. Salah satu energi yang sangat besar pemanfaatannya adalah energi listrik. Pemanfaatan energi listrik terus bertambah mulai dari rumah tangga, perusahaan/ pabrik, perkantoran, dan lain-lain.

Oleh karena meningkatnya kebutuhan tenaga listrik, maka proses penyediaan sumber tenaga listrik yang umumnya berasal dari minyak bumi, fosil, batu bara, dan gas bumi yang akan digunakan sebagai bahan bakar dari sumber tenaga listrik akan dihasilkan dalam jumlah yang terbatas dan suatu saat akan habis dan harganya akan selalu naik.

Banyak daerah - daerah yang belum dapat menikmati listrik, terutama daerah - daerah terpencil. Untuk itu Perusahaan Listrik Negara ( PLN) untuk mensuplai listrik ke daerah - daerah terpencil cukup sulit baik dari segi ekonomis maupun teknis di lapangan karena membutuhkan biaya yang cukup besar sehingga distribusinya tidak sampai ke daerah - daerah terpencil. Maka salah satu cara mengatasi masalah ini adalah pembangkit listrik tenaga Micro Hydro dengan memanfaatkan energi potensial dari air. 


\section{KAJIAN PUSTAKA}

\section{Prinsip Konversi Energi Air}

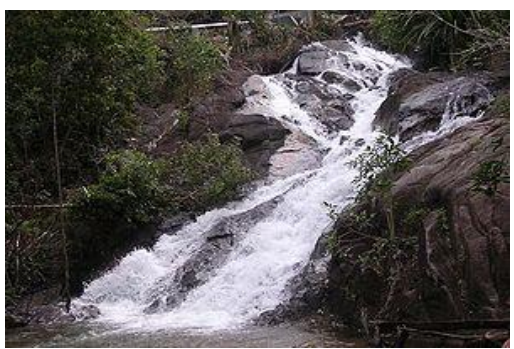

Gambar 1. Energi Air

(sumber:http:/energitakterbatas.blogspot.com/2 013/03hydropower.html)

Aliran air menghasilkan energi yang dapat dijadikan listrik. Ini disebut dengan hydropower (Pembangkit Listrik Tenaga Air). Hydropower saat ini merupakan sumber terbesar dari energi terbarukan. Salah satu Hydropower adalah Pembangkit Listrik Tenaga Micro Hydro (PLTMH) atau dapat disebut Micro Hydro. Sebuah skema Hydro memerlukan dua hal yaitu debit air dan ketinggian jatuh biasa disebut ('head') untuk menghasilkan tenaga yang bermanfaat. Ini adalah sebuah sistem konversi tenaga, menyerap tenaga dari bentuk ketinggian dan aliran, dan menyalurkan tenaga dalam bentuk daya listrik atau daya poros mekanik. Tidak ada sistem konversi daya yang dapat mengirim sebanyak yang diserap dikurangi sebagian daya hilang oleh sistem itu sendiri dalam bentuk gesekan, panas, suara dan sebagainya. . Dibawa ini adalah diagram kebutuhan tenaga potensial air di DUNIA,ASIA,dan INDONESIA

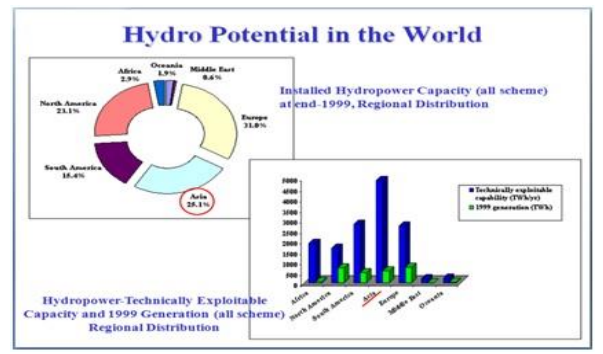

Gambar 2. Diagram Kebutuhan Tenaga Potesial Air Diduni.

(sumber:http:/energitakterbatas.blogspor com/2013/03hydropower.html)

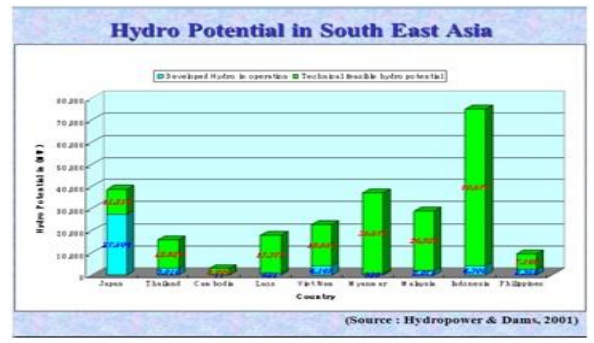

Gambar 3. Diagram Kebutuhan Tenaga

Potensial Air di Asia Tenggara

(sumber:http:/energitakterbatas.blogspor com/2013/03hydropower.html)

Kebutuhan tenaga potensial air di Indonesia 401,646 GWh/tahun (sekitar 74.976 MW).

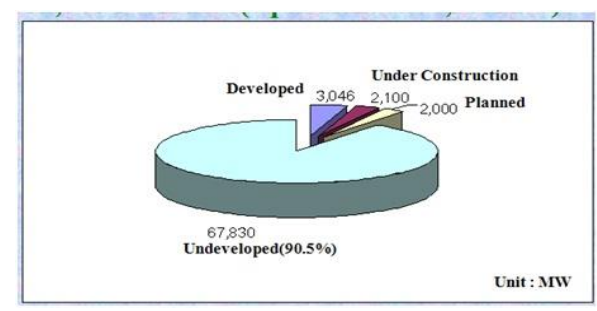

Gambar 4. Diagram Kebutuhan Tenaga

Potensial Air Di Indonesia

(sumber:http:/energitakterbatas.blogspor com/2013/03hydropower.html)

Pada saat ini dunia sedang mengalami krisis energi dan khususnya Indonesia mengalami krisis energi listrik secara nasional. Listrik merupakan salah satu kebutuhan hidup manusia yang primer, sehingga diperlukan suatu instalasi pembangkit tenaga listrik yang efisien. Berbagai macam jenis pembangkit listrik telah banyak dibuat mulai dari turbin gas, turbin uap, turbin air, kincir air dan solar cell dengan berbagai keuntungan dan kelebihan. Pemanfaatan energi tenaga air (hydropower) di Indonesia juga sangat minim. Pengembangan sumber energi yang dapat diperbarahukan semakin meningkat sebagai antisipasi makin berkurangnya sumber energi yang berasal dari fosil seperti minyak bumi dan batubara 


\section{Pengertian Micro Hydro}

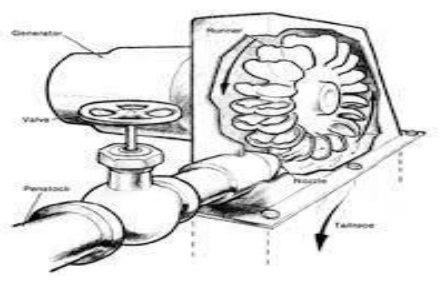

Gambar 5. Micro Hydro

(sumber:http:/energitakterbatas.blogspor com/2013/03hydropower.html)

Micro Hydro atau yang dimaksut pembangkit listrik tenaga Micro Hydro (PLTMH) suatu pembangkit skala kecil yang menggunakan tenaga air sebagai tenaga penggeraknya seperti saluran irigasi,sungai,air terjun alam dan air yang ditampung dibak dengang cara memanfaatkan tinggi terjunan dan jatuhnya air (head) serta jumlah debit air. Micro Hydro merupakan sebua istilah yang terdiri dari kata Micro yang berarti kecil dan Hydro yang berarti air Secara teknis, Micro Hydro memiliki tiga komponen utama yaitu air (sebagai sumber energy), turbin dan generator, Micro Hydro mendapatkan energi dari aliran air yang memiliki perbedaan ketinggian tertentu. Pada dasarnya, Micro Hydro memanfaatkan energi potensial jatuhan air (head). Semakin tinggi jatuhan air maka semakin besar energi potensial air yang dapat diubah menjadi energi listrik.

\section{Prinsip Kerja Micro Hydro}

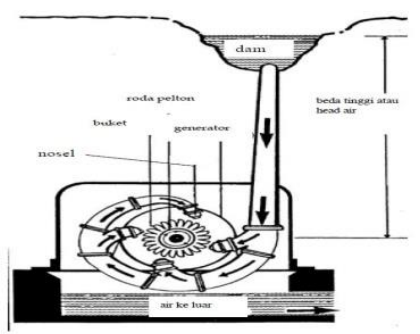

Gambar 6. Prinsip Kerja Micro Hydro

(sumber:http:/energitakterbatas.blogspor com/2013/03hydropower.html)

Prinsip dasar kerja Micro Hydro adalah memanfaatkan energi potensial yang dimiliki oleh aliran air pada jarak ketinggian tertentu dari tempat instalasi pembangkit listrik.

Air yang suda tertampung didalam tangki penampung (reservoir tak) yang diletakan pada ketinggian tertentu mengalir melalui pipa pesat sampai pada nozzle. air yang keluar pada nozzle saluran airnya diperkecil dengan meruba penampang nozzle sehingga air yang keluar memiliki tekanan yang tinggi, membentur sudu turbin dan meruba energi potensial air menjadi energi mekanik pada poros turbin dan dari energi mekanik poros turbin diruba oleh poros generator menjadi energi listrik

\section{Komponen Komponen utama Sistem Micro Hydro}

\section{Generator Listrik Arus DC}

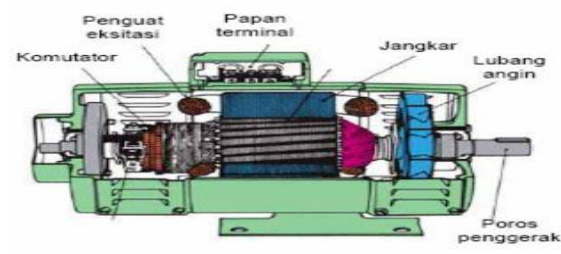

Gambar 7. Konstruksi Generator Listrik DC (Sumber:http//www.Pipercomex.com/2011/09/g eneratorlistrik.hlml)

Generator adalah suatu sistem yang menghasilkan tenaga listrik dengan masukan tenaga mekanik Jadi disini generator berfungsi untuk mengubah tenaga mekanik menjadi tenaga listrik yang mempunyai prinsip kerja sebagai berikut:"Bilamana rotor diputar maka belitan kawatnya akan memotong gaya-gaya magnit pada kutub magnit, sehingga terjadi perbedaan tegangan, dengan dasar inilah timbullah arus listrik, arus melalui kabel/kawat yang ke dua ujungnya dihubungkan dengan cincin geser. Pada cincin-cincin tersebut menggeser sikat-sikat, sebagai terminal penghubung keluar.

Bagian-bagian generator

a) Rotor, adalah bagian yang berputar yang mempunyai bagian terdiri dari poros, inti, kumparan, cincin geser, dan sikat-sikat.

b) Stator, adalah bagian yang tak berputar (diam) yang mempunyai bagian terdiri dari rangka stator yang merupakan salah satu bagian utama dari generator yang terbuat dari besi tuang dan ini merupakan rumah dari semua bagian-bagian generator, 


\section{Turbin Pelton Atau Disebut Juga Turbin Implus}

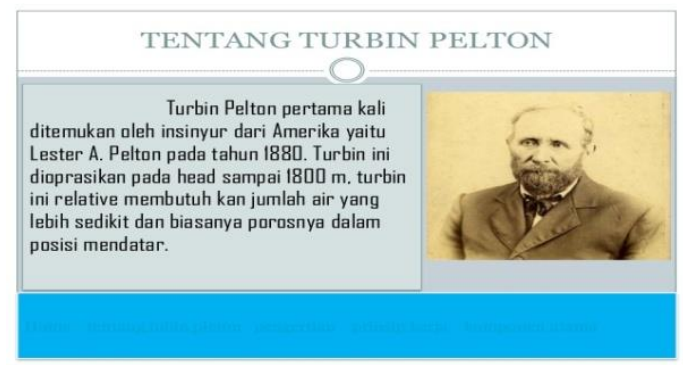

Gambar 8. Penemu Turbin Pelton (sumber:http:/energitakterbatas.blog spor com/2013/03 Turbin pelton.html)

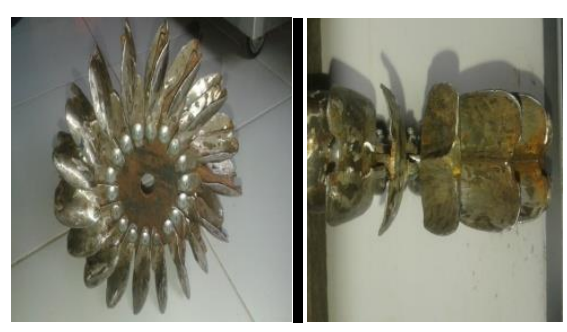

Gambar 9. Roda Jalan Turbin Pelton (sumber:http:/energitakterbatas.blog spor com/2013/03 Turbin pelton.html)

Di dalam penelitian ini penulis menggunakan turbin jenis pelton. Turbin,ini merupakan salah satu bagian penting dalam PLTMH yang menerima energi potensial air dan mengubahnya menjadi putaran (energi mekanis). Putaran turbin dihubungkan dengan generator untuk menghasilkan listrik.

Turbin pelton atau turbin implus sudah dijelaskan pada kincir air. Turbin impuls bekerja dengan prinsip impuls. Turbin jenis ini juga disebut turbin tekanan sama karena aliran air yang ke luar dari Nozzle, tekanannya adalah sama dengan tekanan atmosfer. Adalah turbin pelton yang bekerja dengan prinsip impuls, semua energi tinggi dan tekanan ketika masuk ke sudu jalan turbin dirubah menjadi energi kecepatan. Pancaran air tersebut yang akan menjadi gaya tangensial $\mathrm{F}$ yang bekerja pada sudu roda jalan. Ukuran-ukuran utama turbin pelton adalah diameter lingkar sudu yang kena pancaran air, disingkat diameter lingkaran pancar dan diameter pancaran air. Pengaturan Nozzle akan menentukan kecepatan dari turbin. Untuk turbin-turbin yang bekerja pada kecepatan tinggi jumlah Nozzle diperbanyak Hubungan antara jumlah Nozzle dengan keceptan sepesifik. Pengaturan Nozzle pada turbin dapat dilihat pada gambar dibawa ini
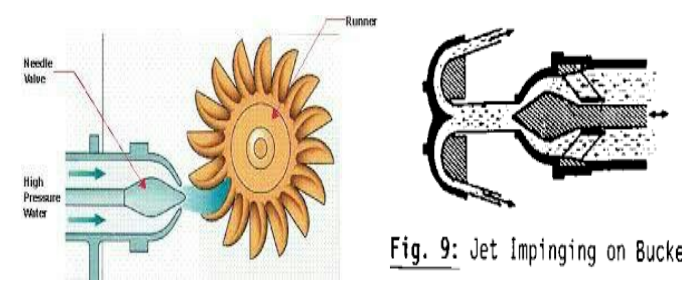

Fig. 9: Jet Impinging on Bucket

Gambar 10. Pengaturan Nozzle Pada Turbin Pelton

(sumber:http:/energitakterbatas.blog spor com/2013/03 Turbin pelton.html)

\section{Pipa Pesat (penstock)}

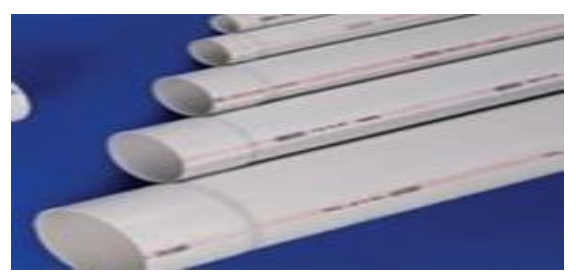

Gambar 11. Pipa Pesat (penstock) (sumber:http://www.pipercomex.com/2013/03 pipaair.html)

Pipa pesat (penstock) adalah pipa yang terbuat dari fiberglass or plastik penstock. Fungsinya adalah untuk mengalirkan air dari tengki penampung menuju turbin. Pipa pesat mempunyai posisi kemiringan yang tajam dengan maksud agar diperoleh kecepatan dan tekanan air yang tinggi untuk memutar turbin. Konstruksinya harus diperhitungkan agar dapat menerima tekanan besar yang timbul termasuk tekanan dari pukulan air.

Pipa pesat (Penstock) sebagai saluran yang ditempatkan berdasarkan perbedaan ketinggian input dan out put atau elevasi yang terhubung langsung dengan turbin dimana pada out put pipa penstock dipasang nozel untuk menambah tekanan air jatuh. Pipa pesat (penstock) adalah saluran yang digunakan untuk mengalirkan air dari sumber air atau dari tangki penampung (head race water) ke rumah turbin. Tangki Penampung (reservoir tank)

Pipa pesat (penstock) adalah saluran yang digunakan untuk mengalirkan air dari sumber air atau dari tangki penampung (head race water) ke rumah turbin. Didalam pembuatan alat ini penulis menggunakan pipa pesat yang berbahan fiber glass or plastik penstock karena bahan ini 
memiliki kekuatan yang tinggi tahan terhadap cuaca panas maupun hujan dan muda ditemukan dipasaran. Untuk ukuran pipa yang akan digunakan pada pembuatan alat ini penulis menggunakan tiga ukuran yaitu pipa yang berukuran 4 inch, 3 inch, dan pipa ukuran 2 inch

\section{Tangki Penampung (reservoir tank)}

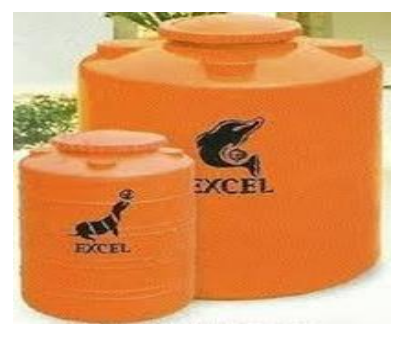

Gambar 12. Tangki Penampung Air (reservoir tank)

(sumber:http://www.siunderexel.com/2013/03 reservoirtank.html)

Tangki penampung ini berfungsi untuk menampung air, sebagai tempat untuk menentukan seberapa besar debit air yang akan digunakan untuk memutar turbin serta menentukan seberapa tinggi jatuhnya air (head) efektif atau (head) standar yang akan digunakan untuk mendapatkan putaran turbin yang maksimal tangki ini diletakan pada tiang penyangga yang memiliki ketinggian 4 meter.

Tangki penampung air ini terbuat dari plastik tebal yang memiliki ketahanan yang cukup lama dan kekuatannya tahan pada kondisi cuaca hujan ataupun panas. Tangki ini dilengkapi lubang sirkulasi udara dibagian penutup tangki untuk mensirkulasikan udara panas didalam tangki tersebut disaat cuaca panas dan memiliki saluran pembuangan air dibagian bawah tangki yang berbentuk kerujuk untuk memaksimalkan tekanan air yang mengalir ke pipa penstock. Tangki ini diproduksi dalam ukuran-ukuran yang berfariasi. Total energi dari suatu reservoir air atau tangki penampung adalah: merupakan energi potensial air.

\section{Metedologi Penelitian}

Penelitian dilakukan dengan mencatat datadata teknis berupa data spesifikasi alat micro hydro seperti terlihat pada tabel 1 .

Pengolahan data dilakukan dengan menganalisis besaran-besaran head dan debit yang dilanjutkan dengan perhitungan daya turbin dan daya generator dari mikro hydro.

Tabel 1. Data Alat Micro Hydro

\begin{tabular}{|l|l|l|}
\hline No. & $\begin{array}{l}\text { Nama } \\
\text { Komponen }\end{array}$ & \multicolumn{1}{|c|}{ Keterangan } \\
\hline 1 & $\begin{array}{l}\text { Generator } \\
\text { DC }\end{array}$ & ALTERNATOR \\
\hline 2 & $\begin{array}{l}\text { Turbin jenis } \\
\text { pelton } \\
\text { sudu turbin yang } \\
\text { terbuat dari sendok sup } \\
\text { kecil, memiliki } \\
\text { diameter dalam turbin } \\
14 \text { cm dan diameter } \\
\text { luar turbin 18 cm }\end{array}$ \\
\hline 3 & $\begin{array}{l}\text { Nozel } \\
\text { pengatur } \\
\text { sudut } \\
\text { semprotan } \\
\text { air }\end{array}$ & $\begin{array}{l}\text { Terbuat dari kran air } \\
\text { terbuat dari besi yang } \\
\text { memiliki pengatur } \\
\text { jumlah aliran air }\end{array}$ \\
\hline 4 & $\begin{array}{l}\text { Pipa pesat } \\
\text { (penstock) }\end{array}$ & $\begin{array}{l}\text { Mengunakan Pipa } \\
\text { paralon merek PVC } \\
\text { ukuran 2,3,4 inch }\end{array}$ \\
\hline 5 & $\begin{array}{l}\text { Tangki } \\
\text { penampung } \\
\text { air }\end{array}$ & $\begin{array}{l}\text { tangki penampungan } \\
\text { air menggunakan } \\
\text { tangki profil tank 2200 } \\
\text { liter }\end{array}$ \\
\hline 6 & $\begin{array}{l}\text { Tiang /kaki } \\
\text { penyangga } \\
\text { tangki } \\
\text { penampung } \\
\text { air }\end{array}$ & $\begin{array}{l}\text { untuk tiang kaki } \\
\text { penyangga } \\
\text { menggunakan besi siku } \\
\text { ukuran 5x50 mm }\end{array}$ \\
\hline $\begin{array}{l}\text { Rumah } \\
\text { turbin }\end{array}$ & $\begin{array}{l}\text { Rumah turbin terbuat } \\
\text { dari plat stainless steel } \\
\text { ukuran 3 mm }\end{array}$ \\
\hline
\end{tabular}

\section{PEMBAHASAN}

\section{Mengukur Debit Air Terhadap Head Actual 6,6 Meter}

Untuk mengukur debit air pada ketinggian 6,6 meter alat ukur yang digunakan adalah stopwatch untuk mengukur waktu dan alat ukur liter untuk mengukur volume air hasil pengukurannya adalah seperti pada tabel dibawa ini. 
Tabel 2. Hasil Pengukuran Debit Air Terhadap Head Actual 6,6 Meter

\begin{tabular}{|l|c|c|c|}
\hline \multicolumn{1}{|c|}{ Pengukuran } & $\begin{array}{c}\text { Head } \\
\text { Actual } \\
\text { (meter) }\end{array}$ & $\begin{array}{c}\text { Debit } \\
\text { air } \\
\text { (liter/s) }\end{array}$ & $\begin{array}{c}\text { Waktu } \\
\text { (s) }\end{array}$ \\
\hline Pertama & 6,6 & 7 & 8,87 \\
\hline Kedua & 6,6 & 7 & 8,80 \\
\hline Ketiga & 6,6 & 7 & 8,78 \\
\hline Keempat & 6,6 & 7 & 8,76 \\
\hline Kelima & 6,6 & 7 & 8,74 \\
\hline Rata rata & 6,6 & 7 & 8,79 \\
\hline
\end{tabular}

\section{Mengukur Debit Air Terhadap Head Actual 6 Meter}

Untuk mengukur Debit air terhadap Head Actual 6 meter alat ukur yang digunakan adalah stopwatch untuk mengukur waktu dan alat ukur liter untuk mengukur volume air hasil pengukurannya adalah seperti pada tabel dibawa ini

Tabel 3. Hasil Pengukuran Debit Air Terhadap Head Actual 6 Meter

\begin{tabular}{|l|c|c|c|}
\hline \multicolumn{1}{|c|}{ Pengukuran } & $\begin{array}{c}\text { Head } \\
\text { Actual } \\
\text { (meter) }\end{array}$ & $\begin{array}{c}\text { Volume } \\
\text { air } \\
\text { (liter/s) }\end{array}$ & $\begin{array}{c}\text { Waktu } \\
\text { (s) }\end{array}$ \\
\hline Pertama & 6 & 6,8 & 8,79 \\
\hline Kedua & 6 & 6,8 & 8,77 \\
\hline Ketiga & 6 & 6,8 & 8,75 \\
\hline Keempat & 6 & 6,8 & 8,74 \\
\hline Kelima & 6 & 6,8 & 8,72 \\
\hline Rata rata & 6 & 6,8 & 8,754 \\
\hline
\end{tabular}

\section{Menghitung Tinggi Jatuh Air (Head Effektif)} Terhadap Head Actual 6,6 Meter

Untuk menghitung tinggi jatuhnya air (Head Effektif) terhadap Head Actual 6,6 meter adalah sebagai berikut :

$$
\begin{aligned}
\text { Head losses } & =\frac{1}{3} \times \text { Head Actual } \\
& =\frac{1}{3} \times 6,6 \text { meter }
\end{aligned}
$$

Head Losses $=2,2$ meter

Jadi Head Effektif untuk tinggi jatuhnya air terhadap Head Actual 6,6 meter adalah sebagai berikut

Head Effektif = Head Actual - Head Losses Dimana diketahui:

Head Actual $=$ 6,6 meter

Head Losses $=2,2$ meter

Maka hasil perhitunganya adalah:

Head Effektif = Head Actual - Head Losses

$$
=6,6 \text { meter }-2,2 \text { meter }
$$

Head Effektif $=4,4$ meter

Menghitung Tinggi Jatuh Air (Head Effektif)

Terhadap Head Actual 6 Meter

Untuk menghitung tinggi jatuhnya air ( Head Effektif) terhadap Head Actual 6 adalah sebagai berikut :

$$
\begin{aligned}
\text { Head losses } & =\frac{1}{3} \times \text { Head Actual } \\
& =\frac{1}{3} \times 6 \text { meter }
\end{aligned}
$$

Head Losses $=2$ meter

Jadi Head Effektif untuk tinggi jatuhnya air terhadap Head Actual 6 meter adalah sebagai berikut

Head Effektif = Head Actual - Head Losses

Dimana diketahui

Head Actual $=6$ meter

Head Losses $=2$ meter

Maka hasil perhitunganya adalah:

Head Effektif = Head Actual - Head Losses

$$
=6 \text { meter }-2 \text { meter }
$$

Head Effektif $=4$ meter

\section{Menghitung Debit Air Pada Head Actual 6,6 Meter}

Untuk melakukan perhitungan Debit air pada Head Actual 6,6 meter sehingga nilai Debit air terhadap Head Actual 6,6 meter adalah sebagai berikut :

$$
\begin{aligned}
Q=\frac{V}{t}=\frac{7}{8,79} & =0,796 \mathrm{l} / \mathrm{s} \\
& =0,000796 \mathrm{~m}^{3} / \mathrm{s}
\end{aligned}
$$

\section{Menghitung Debit Air Pada Head Actual 6} Meter

Untuk melakukan perhitungan Debit air pada Head Actual 6 meter adalah sebagai berikut :

$$
\begin{aligned}
Q=\frac{V}{t}=\frac{6,8}{8,754} & =0,777 \mathrm{l} / \mathrm{s} \\
& =0,000777 \mathrm{~m}^{3} / \mathrm{s}
\end{aligned}
$$

\section{Menghitung Daya Turbin Air Jenis Pelton Pada Head Actual 6,6 Meter}

Untuk melakukan perhitungan daya turbin air tipe pelton pada ketinggian Head Actual 6,6 meter yaitu sebagai berikut :

$$
\begin{aligned}
\mathbf{P} & =\mathbf{Q} \cdot \boldsymbol{\rho} \cdot \mathbf{g} \cdot \mathbf{H} \cdot \boldsymbol{\eta} \mathbf{t} \\
& =0,000796 \times 1000 \times 9,81 \times 4,4 \times 0,8 \\
& =27,499 \text { Watt }
\end{aligned}
$$


Menghitung Daya Turbin Air Jenis Pelton Pada Head Actual 6 Meter

Untuk melakukan perhitungan daya turbin air tipe pelton pada ketinggian (Head Actual) 6 yaitu sebagai berikut :

$$
\begin{aligned}
\mathbf{P} & =\mathbf{Q} \cdot \boldsymbol{\rho} \cdot \mathbf{g} \cdot \mathbf{H} \cdot \boldsymbol{\eta} \mathbf{t} \\
& =0,000777 \times 1000 \times 9,81 \times 4 \times 0,8 \\
& =24,385 \text { Watt }
\end{aligned}
$$

\section{Menghitung Daya Listrik Micro Hydro Pada Head Actual 6,6 Meter}

Perhitungan daya pembangkit listrik tenaga Micro Hydro tipe turbin yaitu sebagai berikut :

$$
\begin{aligned}
\mathbf{P} & =\mathbf{Q} \cdot \boldsymbol{\rho} \cdot \mathbf{g} \cdot \mathbf{H} \cdot \boldsymbol{\eta} \mathbf{t r} \cdot \boldsymbol{\eta} \mathbf{g} \\
& =0,000796 \times 1000 \times 9,81 \times 4,4 \times 0,8 \times 09 \\
& =24,749 \text { Watt }
\end{aligned}
$$

\section{Menghitung Daya Listrik Micro Hydro Pada Head Actual 6 Meter}

Untuk melakukan perhitungan daya pembangkit listrik tenaga Micro Hydro pada Head Actual 6 meter yaitu sebagai berikut:

$$
\begin{aligned}
\mathbf{P} & =\mathbf{Q} \cdot \boldsymbol{\rho} \cdot \mathbf{g} \cdot \mathbf{H} \cdot \boldsymbol{\eta} \mathbf{t r} \cdot \boldsymbol{\eta} \mathbf{g} \\
& =0,000777 \times 1000 \times 9,81 \times 4 \times 0,8 \times 0,9 \\
& =21,946 \text { Watt }
\end{aligned}
$$

\section{Analisis Pengaruh Tinggi Jatuh Air (Head Actual) Terhadap Daya Listrik Micro Hydro Tipe Turbin Pelton}

Sebuah skema Micro Hydro memerlukan dua hal yaitu, debit air dan ketinggian jatuh air (head) untuk menghasilkan tenaga yang dapat dimanfaatkan. Dalam menganalisa pengaruh Tinggi Jatuhnya Air (Head Actual) Terhadap Daya Pembangkit Listrik Tenaga Micro Hydro Tipe turbin pelton perbandingannya seperti pada tabel dibawa ini

Tabel 4. Perbandingan Head Actual, Head Effektif, Debit air, Daya Turbin, Dan Daya Micro Hydro

\begin{tabular}{|c|c|c|c|c|}
\hline $\begin{array}{c}\text { Head } \\
\text { (metual } \\
\text { (mer }\end{array}$ & $\begin{array}{c}\text { Head } \\
\text { Effektif } \\
\text { (meter) }\end{array}$ & $\begin{array}{c}\text { Debit air } \\
\left(\mathrm{m}^{3} / \mathrm{s}\right)\end{array}$ & $\begin{array}{c}\text { Daya turbin } \\
\text { (watt) }\end{array}$ & $\begin{array}{c}\text { Daya } \\
\text { Micro } \\
\text { Hydro } \\
\text { (watt) }\end{array}$ \\
\hline 6,6 & 4,4 & 0,000796 & 27,499 & 24,749 \\
\hline 6 & 4 & 0,000777 & 24,385 & 21,946 \\
\hline
\end{tabular}

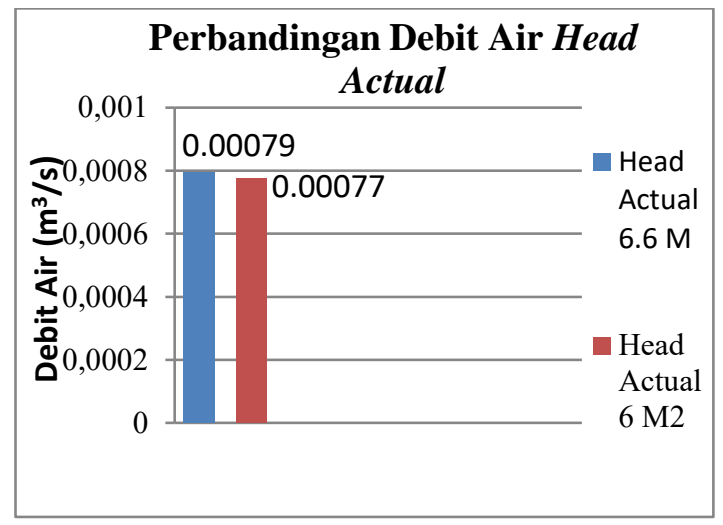

Gambar 1. Grafik Perbandingan Debit Air,

Terhadap Head Actual 6,6 Meter dan 6 Meter

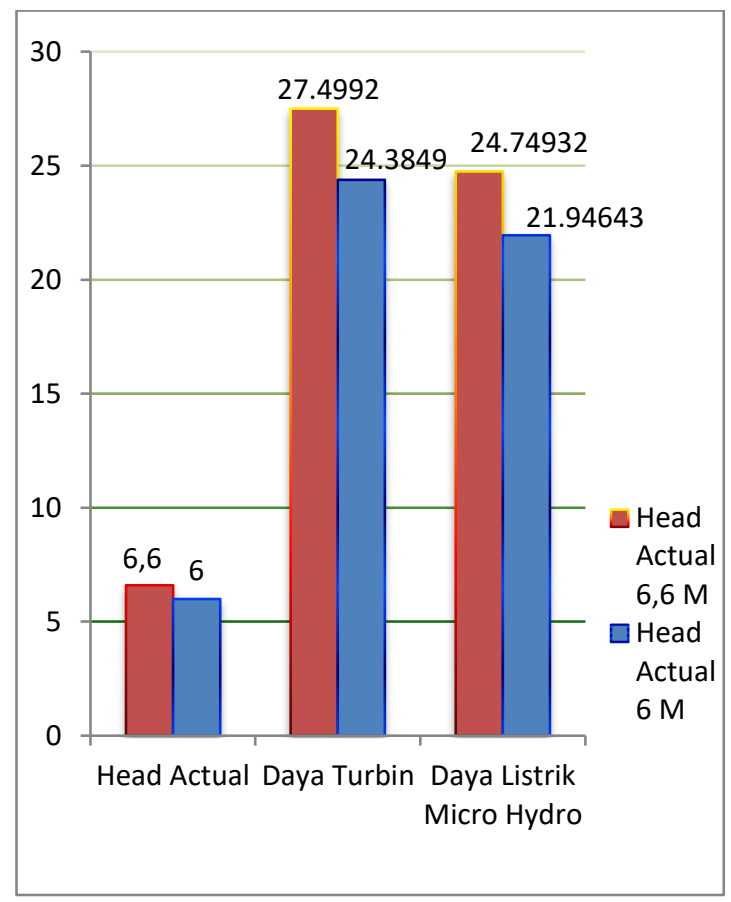

Gambar 2. Grafik Perbandingan Head Actual, Daya Turbin,Dan Daya Listrik Micro Hydro

Sebuah skema Micro Hydro memerlukan dua hal yaitu, debit air dan ketinggian jatuh air (head) untuk menghasilkan tenaga yang dapat dimanfaatkan. Dari gambar grafik 1 dan 2 di atas terlihat bahwa Head Actual dan Debit air sangat mempengaruhi daya listrik yang dihasilkan oleh Micro Hydro. Pada tabel 4 pengukuran di atas terlihat bahwa kenaikan daya dipengaruhi oleh tinggi Head Actual dan Debit air yang banyak. Semakin tinggi jatuh air (Head Actual) dan semakin banyak Debit air yang keluar dari Nozzle maka semakin besar juga tegangan listrik yang dihasilkan oleh Micro Hydro. 


\section{Kesimpulan}

\section{PENUTUP}

Dari hasil pembahasan yang diperoleh diatas, penulis menyimpulkan bahwa :

1. Pada Head Actual 6,6 meter dengan Head Effektik 4,4 meter menghasilkan debit air $0,000796 \mathrm{~m}^{3} / \mathrm{s}$, daya turbin 27,499 Watt dan daya Micro Hydro 24,749 Watt.

2. Sedangkan pada Head Actual 6 meter dengan Head Effektif 4 meter menghasilkan debit air $0,000777 \mathrm{~m}^{3} / \mathrm{s}$, daya turbin 24,385 Watt dan daya micro hydro 21,946 Watt.

\section{Saran}

Dari materi yang telah dibahas diatas, maka penulis memberikan beberapa saran :

1. Dalam melakukan perhitungan dan menganalisa pengaruh tinggi jatuhnya air (Head) terhadap daya listrik yang dihasilkan membutuhkan keseriusan dan kesabaran.

2. Dalam melakukan pengukuran untuk pengambilan data diperlukan kehatihatian untuk memanjat tower.

\section{DAFTAR PUSTAKA}

Astu Pudjanarsa, Djati Nursuhud 2013. Mesin Konversi Energi. Yogyakarta. Andi Offset

Prof. Dipl. Ing Frite Dietzel 1992. Turbin Pompa \& Kompresor. Jakarta. Airlangga

Kamal S. Prayitno 2005. Pengembangan Gorlov Hedical Turbine Untuk Pemanfaatan Arus Air Pada Pembangkit Listrik Terapung Dengan Apungan Berbentuk Nozel

Sutisna N. 2004. Departemen Energi Kembangkan Sistem Microhidro

Zulkarnain, Soekarno, H. Berlian A. 2002. Sistem Piko Hidro Untuk Daerah Terpencil.

Tobi, M.D. and VAN HARLING, V.N., 2017. STUDI PERENCANAAN PEMBANGUNAN PLTMH DI KAMPUNG SASNEK DISTRIK SAWIAT KABUPATEN SORONG SELATAN PROVINSI PAPUA BARAT. Electro Luceat, 3(1), pp.32-43. http:/energitakterbatas.blog spor com/2013/03 Turbin pelton.html (Diakses April 2016)

http://www.pipercomex.com/2013/03 pipaair.html (Diakses April 2016)

http://www.siunderexel.com/2013/03 reservoirtank.html (Diakses April 2016)

http:/energitakterbatas.blog sporcom/2013/03 hydropower.html (Diakses April 2016)

http//www.Pipercomex.com/2011/09/generator listrik.hlml (Diakses April 2016) 